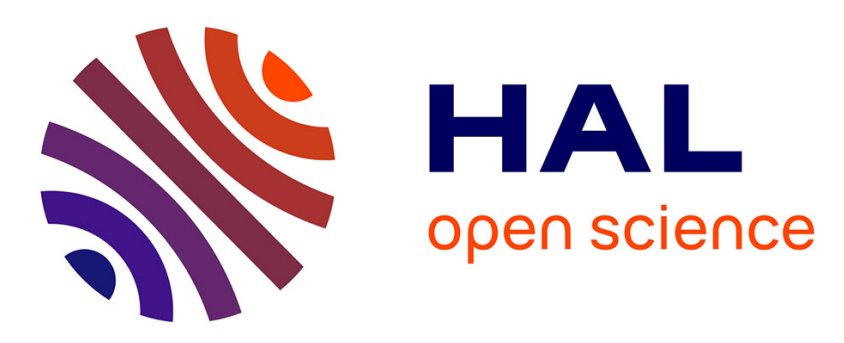

\title{
DNA vaccination induces WT1-specific T-cell responses with potential clinical relevance.
}

\author{
Coralie Chaise, Sarah L Buchan, Jason Rice, Jeanine Marquet, Hélène
}

Rouard, Mathieu Kuentz, Gisella E Vittes, Valérie Molinier-Frenkel, Jean-Pierre Farcet, Hans J Stauss, et al.

\section{To cite this version:}

Coralie Chaise, Sarah L Buchan, Jason Rice, Jeanine Marquet, Hélène Rouard, et al.. DNA vaccination induces WT1-specific T-cell responses with potential clinical relevance.. Blood, 2008, 112 (7), pp.295664. 10.1182/blood-2008-02-137695 . inserm-00343343

\section{HAL Id: inserm-00343343 https://www.hal.inserm.fr/inserm-00343343}

Submitted on 1 Dec 2008

HAL is a multi-disciplinary open access archive for the deposit and dissemination of scientific research documents, whether they are published or not. The documents may come from teaching and research institutions in France or abroad, or from public or private research centers.
L'archive ouverte pluridisciplinaire HAL, est destinée au dépôt et à la diffusion de documents scientifiques de niveau recherche, publiés ou non, émanant des établissements d'enseignement et de recherche français ou étrangers, des laboratoires publics ou privés. 
DNA VACCINATION INDUCES WT1-SPECIFIC T-CELL RESPONSES WITH POTENTIAL CLINICAL RELEVANCE.

*Coralie Chaise ${ }^{1,2}$, *Sarah L. Buchan ${ }^{3}$, Jason Rice ${ }^{3}$, Jeanine Marquet ${ }^{1,2}$, Hélène

Rouard $^{4}$, Mathieu Kuentz ${ }^{5}$, Gisella E. Vittes ${ }^{3}$, Valérie Molinier-Frenkel ${ }^{1,2,6}$, Jean-Pierre

Farcet $^{1,2,6}$, Hans J. Stauss ${ }^{7}$, Marie-Hélène Delfau-Larue ${ }^{1,2,6}$ and Freda K. Stevenson ${ }^{3}$.

*These authors contributed equally to this work.

${ }^{1}$ INSERM U-841, IMRB, Département d'Immunologie, dermatologie et Oncologie, Equipe $\mathrm{n}^{\circ}$ 9, Créteil, F-94000 France; ${ }^{2}$ Université Paris 12, Faculté de Médecine, Créteil, F-94000 France; ${ }^{3}$ Genetic Vaccine Group, Somers Cancer Research Building, Southampton University Hospitals Trust, Southampton SO16 6YD, United Kingdom; ${ }^{4}$ Laboratoire de Thérapie Cellulaire, EFS, Créteil, F-94000 France; ${ }^{5}$ AP-HP, Hôpital Henri Mondor, Service d'Hématologie clinique, Créteil, F-94000 France ; ${ }^{6}$ AP-HP, Hôpital Henri Mondor, Service d'Immunologie biologique, Créteil, F-94000 France; ${ }^{7}$ Department of Immunology and Molecular Pathology, Royal Free Hospital, London, United Kingdom.

Short title: Targeting WT1-expressing tumor by DNA vaccination

Corresponding authors:

1. Professor F. K. Stevenson,

Genetic Vaccines Group,

Somers Cancer Research Building,

Southampton University Hospitals Trust,

Southampton SO16 6YD,

United Kingdom.

E-mail: $\underline{\text { ss@soton.ac.uk }}$

Tel: +44 2380796923

Fax: +442380701385

Scientific Category: Neoplasia

Total word count: 4914

Abstract word count: 200
2. Prof. M-H Delfau-Larue

Hôpital Henri Mondor,

Service d'Immunologie Biologique,

51 avenue du Marechal de Lattre de Tassigny,

94010 CRETEIL Cedex,

France.

Email: marie-helene.delfau-larue@hmn.aphp.fr

Tel: +330149812665

Fax: +330149812897 


\section{ABSTRACT}

The Wilms' tumor antigen, WT1, is associated with several human cancers including leukemia. We have evaluated WT1 as an immunotherapeutic target using our proven DNA fusion vaccine design, p.DOM-peptide, encoding a minimal tumor-derived MHC class Ibinding epitope downstream of a foreign sequence (DOM) of tetanus toxin. Three p.DOMpeptide vaccines, each encoding a different WT1-derived, HLA-A2-restricted epitope, induced cytotoxic $\mathrm{T}$ lymphocytes (CTL) in humanized transgenic mice expressing chimeric HLA-A2, without affecting hematopoietic stem cells. Mouse CTL killed human leukemia cells in vitro indicating peptide processing/presentation. Low numbers of $\mathrm{T}$ cells specific for these epitopes have been described in cancer patients. Expanded human T cells specific for each of the three epitopes were lytic in vitro. Focussing on human WT1 $1_{37-45}$-specific cells, the most avid of the murine responses, we demonstrated lysis of primary leukemias, underscoring their clinical relevance. Finally we showed that these human CTL kill target cells transfected with the relevant p.DOM-peptide DNA vaccine, confirming that WT1-derived epitopes are presented to $\mathrm{T}$ cells similarly by tumors and following DNA vaccination. Together, these data link mouse and human studies to suggest that rationally-designed DNA vaccines encoding WT1-derived epitopes, particularly WT1 $1_{37-45}$, have the potential to induce/expand functional tumor-specific cytotoxic responses in cancer patients. 


\section{INTRODUCTION}

Despite major advances in chemotherapy and hematopoïetic stem cell transplantation, many patients with leukemia will relapse because of re-emergence of tumor. However, complete molecular remissions have been achieved by infusion of donor lymphocytes into patients, demonstrating that reactive $\mathrm{T}$ cells are able to eradicate leukemic cells in vivo. ${ }^{1}$ Recently, various leukemia-associated antigens that are recognized by cytotoxic T lymphocytes (CTL) in the context of MHC class I have been identified. ${ }^{2}$ One promising candidate is the Wilms' tumor antigen, WT1, which is expressed by the majority of acute leukemias (both acute lymphoid leukemia (ALL) and acute myeloid leukemia (AML)), blast crisis of chronic myeloid leukemia (CML) and many solid tumours including those of lung, breast and colon. ${ }^{3-}$

6 The finding that blockade of WT1 function in primary leukemic cells significantly slows cell growth in vitro, ${ }^{7}$ additionally suggests that WT1 is of critical importance to the tumor phenotype and that tumor escape by simple WT1 down-modulation is unlikely to occur. In healthy adults, despite ubiquitous expression during embryogenesis, WT1 expression is limited to renal podocytes, gonadal cells and a low frequency of hematopoietic precursor $\mathrm{CD} 4^{+}$cells, ${ }^{4 ; 8-11}$ where it is expressed at significantly lower levels than those described in tumors (10-100-fold). ${ }^{4}$ These features indicate that WT1 could be a useful target for therapeutic vaccination.

Antibodies to WT1 ${ }^{12-14}$ and WT1-peptide specific $\mathrm{CD}^{+} \mathrm{T}$ cells ${ }^{15-17}$ have been detected in $\mathrm{AML}$ and CML patients, confirming that tolerance is incomplete. Furthermore, the presence of WT1-specific T cells correlates with graft-vs-leukemia $(\mathrm{GvL})$ effects following allogeneic stem cell transplantation in ALL patients, ${ }^{18}$ implying that expansion of the WT1-responsive repertoire in leukemic patients may help to mediate tumor clearance. 
Facilitating the study of WT1-specific immunotherapeutic approaches, several MHC class Irestricted peptides have been identified, including the HLA-A*0201-restricted WT1.126 (WT1 $1_{126-134}$; RMFPNAPYL) and the HLA-A*0201 and A*24-restricted WT1.235 (WT1 $1_{235-}$ 243; CMTWNQMNL) epitopes. ${ }^{19-21}$ T cells with specificity for WT1.126 or WT1.235 have been isolated from the peripheral blood of HLA-A2 ${ }^{+}$leukemic patients, ${ }^{15 ; 22 ; 23}$ although evaluation of lytic ability has been limited to HLA-A2 ${ }^{+}$WT1.126-specific cells which were shown to lyse tumor cell lines. ${ }^{22}$ Recently a novel HLA-A2-binding epitope, WT1.37 (WT1 $1_{37-45}$; VLDFAPPGA) was identified. ${ }^{24}$ High-avidity T cells with WT1.37-specificity were expanded from patients with CML and AML although the cytotoxic capacity of these cells was untested. ${ }^{15}$

Surprisingly few groups have investigated vaccine strategies to increase the frequency of clinically-relevant WT1-specific T cells in vivo. Nevertheless clinical trials are underway using the WT1.126 or WT1.235 peptides mixed with adjuvant and some responses in recipients have been reported..$^{23 ; 25 ; 26}$ An early study reported that vaccination using WT1.126 peptide with keyhole limpet hemocyanin plus GM-CSF induced complete remission in the first tested patient with AML. ${ }^{23}$ However, both the functionality of the induced WT1-reactive $\mathrm{T}$ cells and the means to achieve significant levels of response in patients require further investigation.

We have previously described a novel DNA fusion vaccine ${ }^{27 ; 28}$ which encodes a tumorderived antigen fused to the Fragment $\mathrm{C}(\mathrm{FrC})$ of tetanus toxin to provide $\mathrm{CD} 4^{+} \mathrm{T}$-cell help, critical for the induction of long-term anti-tumor immunity. ${ }^{29-31}$ Minimizing the FrC sequence to a single domain (DOM) incorporating the MHC class II-restricted peptide, $\mathrm{p} 30,{ }^{32 ; 33}$ reduces the potential for peptide competition. Fusing this single domain to a target MHC class I- 
restricted epitope then enhances induction of epitope-specific CTL capable of eliminating tumor cells. ${ }^{34 ; 35}$ These optimized DNA fusion vaccines, termed p.DOM-peptide, are capable of inducing high levels of epitope-specific CTL from a tolerized repertoire, likely due to provision of high levels of T-cell help via the anti-microbial repertoire. ${ }^{36}$

In the present study, we used humanized HLA-A2 transgenic mice ${ }^{37}$ to model a WT1 vaccination strategy based on our optimized p.DOM-peptide design. This model has value for testing the ability of vaccines to induce $\mathrm{CD}^{+} \mathrm{T}$-cell responses restricted by the human HLAA2 haplotype and for demonstrating that the target peptide is naturally processed and presented. $^{38}$ Murine and human WT1 share a similar expression pattern and $96 \%$ identity at the amino acid level, ${ }^{39}$ with all three HLA-A2-restricted epitopes identical in the two species. Thus WT1-specific immune tolerance is expected to be similar in HLA-A2 transgenic mice and humans, making humanized mice an ideal test-bed for clinical vaccination approaches aimed at breaking tolerance to WT1. We show that T cells with specificity for all three WT1derived epitopes can be expanded by vaccination and can kill human leukemic cells. To make a clinical connection, and demonstrate a potential T-cell repertoire, we additionally showed that expanded WT1.37-specific human HLA-A2 ${ }^{+} \mathrm{T}$ cells from healthy donors were able to lyse primary leukemia cells. The ability of our vaccine design to present peptide to these $\mathrm{T}$ cells and therefore expand the repertoire was shown by transfecting human cells with the relevant p.DOM-peptide DNA vaccine. Thus, we suggest that vaccinating patients with p.DOM-peptide DNA vaccines to expand functional WT1-specific T cells, including those with specificity for WT1.37, may be an efficient means to induce cancer-specific cytotoxicity in patients with leukemia. 


\section{MATERIALS AND METHODS}

\section{Construction of DNA vaccines}

DNA vaccines are shown schematically in Figure 1. Construction of the p.DOM plasmid containing the gene encoding the first domain of $\mathrm{FrC}$ of tetanus toxin (DOM, $\mathrm{TT}_{865-1120}$ ) with a leader sequence derived from the $\mathrm{V}_{\mathrm{H}}$ of the IgM of the $\mathrm{BCL}_{1}$ tumour at the $\mathrm{N}$-terminus has been previously described. ${ }^{35}$ Three additional DNA vaccines were constructed encoding either $\mathrm{WT}_{37-45}$ (WT1.37; p.DOM-WT1.37), WT1 $1_{126-134}$ (WT1.126; p.DOM-WT1.126) or $\mathrm{WT}_{235-243}$ (WT1.235; p.DOM-WT1.235) peptides fused directly 3 ' to DOM. p.DOMWT1.126 was constructed by PCR amplification using p.DOM as template with the forward primer 5'-TTTTAAGCTTGCCGCCACCATGGGTTGGAGC-3' and the reverse primer 5'TTTTGCGGCCGCTTACAGGTAGGGCGCATTGGGGAACATCCTGTTACCCCAGAAG TCACGCAGGAA-3'. The PCR product was gel purified, digested using HindIII and NotI restriction sites and cloned into the expression vector pcDNA3 (Invitrogen, Paisley, U.K). The vaccines p.DOM-WT1.235 and p.DOM-WT1.37 were constructed similarly using the same forward primer and reverse primers 5'-TTTGCGGCCGC TTATAAGTTCATCTGATTCCAGGTCATGCAGTTACCCCAGAAGTCACGCAGGAA$3^{\prime}$

and

TTTGCGGCCGCTTAAGCGCCCGGAGGCGCAAAGTCCAGCACGTTACCCCAGAAGT CACGCAGGAA-3', respectively. Restriction sites within primers are italicised and WT1peptide encoding sequences are underlined. Integrity of the inserted sequence was confirmed by DNA sequencing and translated product size was checked in vitro using the TNT T7 coupled reticulocyte lysate system (Promega, Southampton, U.K.).

\section{Peptides}


The HLA-A*0201-restricted WT1.37 (VLDFAPPGA), WT1.126 (RMFPNAPYL), WT1.235 (CMTWNQMNL) peptides $^{19-21}$ and the HLA class II-restricted p30 (FrC-derived: TTFNNFTVSFWLRVPKVSASHLE) ${ }^{33}$ and PADRE (KSSAKXVAAWTLKAAA:

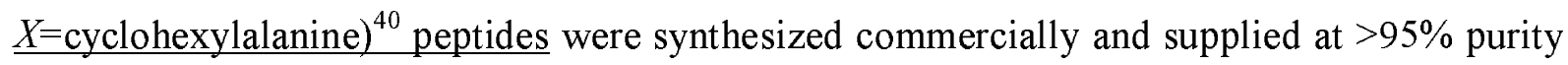
(PPR Ltd, Southampton, U.K.).

\section{HHD transgenic mice}

HHD mice express a transgenic chimeric monochain MHC class I molecule in which the $\mathrm{COOH}$-terminus of human $\beta_{2}$-microglobulin is covalently linked to the $\mathrm{NH}_{2}$-terminus of chimeric HLA-A2 $\alpha 1$ and $\alpha 2$ domains fused with the murine $H-2 D^{b} \alpha 3$ domain. These mice lack cell-surface expression of mouse endogenous $\mathrm{H}-2^{\mathrm{b}}$ class I molecules due to targeted disruption of the $\mathrm{H}-2 \mathrm{D}^{\mathrm{b}}$ and mouse $\beta_{2}$-microglobulin genes. ${ }^{37}$

\section{Vaccination protocol}

HHD mice at 6 to 10 weeks of age were injected intramuscularly (i.m.) into both quadriceps with a total of $50 \mu \mathrm{g}$ DNA in saline solution on day 0 . Unless stated otherwise mice were boosted with the same DNA vaccine delivered with in vivo electroporation on day 28 as previously described. ${ }^{41}$ For comparing DNA and peptide vaccination, mice were immunized i.m. with p.DOM-WT1.126 or subcutaneously into 2 sites on the flanks with a total of $50 \mu \mathrm{g}$ $\underline{\text { WT1.126 and } 100 \mu \mathrm{g} \text { PADRE peptides mixed together. Peptides were administered with an }}$ equal volume of Incomplete Freunds Adjuvant (IFA). Splenocytes were harvested 10 days later for analysis. Animal experimentation was conducted within local Ethical Committee and UK Coordinating Committee for Cancer Research (London, U.K) guidelines under Home Office License. 
Mouse IFN $\gamma$-ELISpot

$\underline{\text { Vaccine-specific IFN } \gamma \text { secretion by lymphocytes from individual mice was assessed ex vivo }}$ (BD ELISpot Set, BD PharMingen, San Diego, CA) on day 10 or 36, as described previously. ${ }^{36}$ Briefly, viable lymphocytes were selected from splenocyte preparations by density centrifugation. Cells $\left(2-4 \times 10^{5}\right.$ cells/well $)$ were incubated in complete medium (RPMI 1640, 1mM sodium pyruvate, $2 \mathrm{mM}$ L-glutamine, non-essential amino acids (1\% of 100X stock), $50 \mu \mathrm{M} 2$-mercaptoethanol, $100 \mathrm{U} / \mathrm{mL}$ penicillin, $100 \mu \mathrm{g} / \mathrm{mL}$ streptomycin, (all Invitrogen) with $10 \%$ heat-inactivated foetal calf-serum) with WT1.37, WT1.126 or WT1.235 peptides to assess $\mathrm{CD}^{+}$T-cell responses, or with $\mathrm{p} 30$ peptide or PADRE peptide to assess $\mathrm{CD}^{+} \mathrm{T}$ cells. Samples were plated in triplicate; control samples were incubated without peptide or with an irrelevant HLA-A2-binding peptide. Data are expressed as the frequency of spot-forming cells (SFCs) per million lymphocytes. For analysis of peptide-specific T-cell sensitivity, splenic lymphocytes from immunized mice were incubated with a range of WT1 peptide concentrations and the frequency of specific cells assessed by ELISpot analysis as described. The number of SFC/million cells at the peptide concentration inducing the greatest response was assigned a value of $100 \%$. For each peptide concentration tested the $\%$ maximal response was then calculated by the formula: (experimental SFCs per million cells / maximal SFCs per million cells) x $100 \%$ for each individual animal.

\section{Murine cytotoxic T cell expansion and detection}

For the generation and maintenance of CTL lines, mice were sacrificed at the indicated time points and cell suspensions made from each spleen. Splenocytes were washed and resuspended in $10-15 \mathrm{~mL}$ complete media per spleen in upright $25-\mathrm{cm}^{2}$ flasks together with WT1.37 $\left(10^{-9} \mathrm{M}\right)$, WT1.126 $\left(10^{-6} \mathrm{M}\right)$ or WT1.235 $\left(10^{-6} \mathrm{M}\right)$ peptides. Following 7-10 days of stimulation in vitro, cytolytic activity of the T-cell cultures was assessed. For further cycles 
of in vitro re-stimulation, CTL were washed, resuspended at $3 \times 10^{5} / \mathrm{mL}$ with $2.5 \times 10^{6} / \mathrm{mL}$ syngeneic splenocytes pre-incubated for 1 hour with the relevant peptide at $10^{-9} \mathrm{M}$ (WT.37) or $10^{-6} \mathrm{M}$ (WT.126 and WT1.235), washed 4 times in unsupplemented RPMI 1640 (Invitrogen) and irradiated at 2,500 rad. Recombinant human interleukin-2 was added to cultures at 20 IU/mL (IL-2; Perkin-Elmer, Foster City, CA) and cells were incubated at $2 \mathrm{~mL} /$ well of a 24 well plate. Subsequent cycles of in vitro re-stimulation were carried out similarly every 10-12 days. Specific cytotoxic activity was assessed by standard $4-5$ hour ${ }^{51} \mathrm{Cr}$ release assay as previously described. $^{42}$

\section{Assessment of autoimmune damage}

For the detection of autoimmune damage to colony-forming cells in bone marrow, HHD mice were vaccinated as indicated on day 0 and day 28 ( + electroporation). Between days 36 and 42, mice were culled and bone marrow cells collected under aseptic conditions prior to incubation in Methocult ${ }^{\mathbb{Q}}$ media containing $\mathrm{IL}-3, \mathrm{SCF}, \mathrm{IL}-6$ and erythropoietin according to the manufacturer's instructions (StemCell Technologies, London, U.K.). Colonies of hematopoietic cells were enumerated on day 9-11 of in vitro incubation.

\section{Patients and healthy donors}

PBMCs from 10 HLA-A*0201-positive healthy subjects were isolated from leukapheresis using Ficoll-Hypaque density-gradient centrifugation and subsequently cryopreserved in complete medium supplemented with $20 \%$ heat-inactivated $\mathrm{AB}$ serum (SAB) and $10 \%$ DMSO. Tumor cells from 6 patients with $\mathrm{WT}^{+}$acute leukemias were isolated from one HLA-A*0201-positive patient with ALL (patient I), three from HLA-A*0201-positive patients with AML (patients II, III and IV) and two from HLA-A*0201-negative patients with AML (patients V and VI). WT1 expression was confirmed by WT1-specific RT-PCR (data 
not shown). Informed consent was obtained from all healthy subjects and patients before blood sampling

\section{Cell lines and autologous PHA blasts}

Cells used as targets in murine CTL assays were the human leukemia lines C1RA2 (WT1 ${ }^{-}$ HLA-A $\left.{ }^{*} 0201^{+}\right)$, KYO-1 $\left(\mathrm{WT}^{+}{ }^{+} \mathrm{HLA} \mathrm{A}^{*} 0201^{-}\right)$or $697\left(\mathrm{WT}^{+}{ }^{+} \mathrm{HLA}-\mathrm{A}^{*} 0201^{+}\right)$either alone, or retrovirally-transduced with HHD DNA using standard methods. For human in vitro studies the pro-B cell line RS 4,11 (WT1 $1^{+} \mathrm{HLA}-\mathrm{A}^{*} 0201^{+}$) was purchased from American Type Culture Collection (ATCC, Rockville, USA), the pre-B leukemia cell line 697 and follicular lymphoma cell line VAL (WT1HLA-A*0201 ${ }^{+}$) were purchased from Deutsche Sammlung von Mikroorganismen und Zellkulturen (DSMZ, Braunschweig, Germany). PHA-Blasts were differentiated from non-adherent PBMC $\left(1 \times 10^{6}\right.$ cells $\left./ \mathrm{mL}\right)$ by culture in complete medium supplemented with 10\% SAB (RPMI 10\% SAB), $50 \mathrm{IU} / \mathrm{mL}$ IL-2 (R\&D systems, Oxford, U.K) and $2 \mu \mathrm{g} / \mathrm{mL}$ phytohemagglutinin (Sigma-Aldrich, Saint Quentin Fallavier, France). IL$2(50 \mathrm{IU} / \mathrm{mL})$ was added every 2 to 3 days.

\section{Human cytotoxic T cell expansion}

Dendritic cells (DC) were generated from donor monocytes as previously described. ${ }^{43}$ Briefly, adherent PBMCs were cultured at $10 \times 10^{6}$ cells/well in 6-well plates with $100 \mathrm{ng} / \mathrm{mL}$ IL-4 and $80 \mathrm{ng} / \mathrm{mL}$ GM-CSF in AIM V serum free medium (Invitrogen) for 1 day. Maturation was induced by additional 24 hour incubation with $10 \mathrm{ng} / \mathrm{mL}$ TNF- $\alpha, 20 \mathrm{ng} / \mathrm{mL}$ IL-6, $1 \mu \mathrm{g} / \mathrm{mL}$ PGE-2 and $10 \mathrm{ng} / \mathrm{mL} \mathrm{IL-1 \beta}$ (all R\&D Systems, Abingdon, U.K.). Mature DC pulsed for 2 hours at $37^{\circ} \mathrm{C}$ with $10 \mu \mathrm{g} / \mathrm{mL}$ of WT1-derived peptide in AIM V were then irradiated (50 Gy), washed in RPMI 10\% SAB and used as stimulator cells. Autologous $\mathrm{CD}^{+} \mathrm{T}$ cells were purified from healthy HLA-A*0201-positive donor PBMC by positive 
selection using CD8 magnetic microbeads (Miltenyi Biotech SAS, Paris, France). The binding fraction was adjusted to $5 \times 10^{6}$ cells $/ \mathrm{mL}$ while the $\mathrm{CD} 8$-negative fraction was irradiated (30 Gy) and adjusted to $5 \times 10^{6}$ cells $/ \mathrm{mL}$ to be used as helpers. $\mathrm{CD}^{+} \mathrm{T}$ cells were then plated together with stimulator DC at a $10: 1$ or $5: 1$ ratio and with helpers at a $2: 1$ ratio in RPMI 10\% SAB. IL-2 (25 IU/mL) and IL-7 (5 ng/mL; R \& D Systems) were added every 2 to 3 days from day 3 . One million CTL were restimulated every 10 days in 24-well plates with autologous adherent monocytes from $4 \times 10^{6}$ PBMCs pulsed with $5 \mu \mathrm{g} / \mathrm{mL}$ relevant peptide and $100 \mathrm{ng} / \mathrm{mL} \beta_{2}$-microglobulin (Sigma-Aldrich) in serum-free RPMI 1640. IL-2 $(25 \mathrm{IU} / \mathrm{mL})$ and $\mathrm{IL}-7(5 \mathrm{ng} / \mathrm{mL})$ were added every 2 to 3 days.

\section{Human cytotoxic T cell detection}

$\mathrm{CD}^{+} \mathrm{T}$ cells specific for WT1 peptides were quantified by double-staining using biotinylated HLA-A*0201/WT1.126 or HLA-A*0201/WT1.235 pentamers (Proimmune, Oxford, U.K) and PE-Cy5-coupled anti-CD8 antibody (clone 3B5, Caltag, Burlingame, USA). Briefly, $5 \mathrm{x}$ $10^{5} \mathrm{~T}$ cells were incubated for 30 mins on ice with $0.5 \mu \mathrm{g}$ pentamer, washed and incubated for a further 20 mins at $4{ }^{\circ} \mathrm{C}$ with $5 \mu \mathrm{L}$ anti-CD8 antibody and $200 \mathrm{ng}$ streptavidin-PE (Invitrogen) concurrently. Fluorescence was determined using a FACS FC500 (Beckman Coulter, Villepinte, France). For determining cytotoxic activity, target cells were either peptide-pulsed $\left(10 \mu \mathrm{g} / \mathrm{mL}\right.$ peptide plus $100 \mathrm{ng} / \mathrm{mL} \beta_{2}$-microglobulin 2 hours at $\left.37^{\circ} \mathrm{C}\right)$ or unpulsed and labelled with ${ }^{51} \mathrm{Cr}$ sodium chromate for 1 hour at $37^{\circ} \mathrm{C}$ before plating at $2.5 \mathrm{x}$ $10^{3}$ cells/well in a 96-well plate. Cytolytic activity at graded effector to target ratios was determined in a standard 4 hour ${ }^{51} \mathrm{Cr}$-release assay. In some experiments, target cells were incubated with the anti-human HLA-class I monoclonal antibody W6.32 (Diaclone SAS, Besançon, France) or with IgG2a isotype control ( $5 \mu \mathrm{g} /$ well) for $15 \mathrm{~min}$ at $4{ }^{\circ} \mathrm{C}$ before the addition of $\mathrm{T}$ cells and for the duration of the assay. Means of triplicate cultures were 
expressed as (experimental release - spontaneous release)/(total ${ }^{51} \mathrm{Cr}$ incorporated spontaneous release) $\times 100 \%$. The average spontaneous release never exceeded $15 \%$ of the total incorporated ${ }^{51} \mathrm{Cr}$.

VAL cell line transfection

VAL cells $\left(5 \times 10^{6}\right.$ cells) were transfected with $5 \mu \mathrm{g}$ of plasmid (p.DOM, p.DOM-WT1.37 or p.EGFPmax) using the Amaxa Nucleofector apparatus (Amaxa, Cologne, Germany) according to the manufacturer's protocol for human B cells. Flow cytometry analysis of p.EGFPmax (Amaxa)-transfected cells showed a transfection efficiency of between $60-70 \%$ at 24 hours. Cells were used as targets in a ${ }^{51} \mathrm{Cr}$-release assay at this time point. 


\section{RESULTS}

p.DOM-WT1 vaccines induce WT1-specific T-cell responses in HHD mice

Three DNA vaccines were constructed, each encoding the first domain of $\mathrm{FrC}$ of tetanus toxin (DOM) fused to a minimal WT1-derived peptide sequence, and conforming to our previously described vaccine design. ${ }^{34-36}$ Specifically, vaccines were p.DOM-WT1.37, p.DOMWT1.126 and p.DOM-WT1.235, each incorporating sequence encoding the promiscuous helper T-cell epitope, p30, and one of the three MHC class I-binding peptides, WT1.37, WT1.126 or WT1.235 respectively (Figure 1). To test vaccine efficacy humanized HHD mice were immunized on days 0 and 28 with one of the p.DOM-WT1-peptide vaccines, or with the control vaccine p.DOM. The booster injection on day 28 was immediately followed by in vivo electroporation at the site of injection, a technique we have previously shown to be of benefit for the activation of T-cell responses, particularly at boosting. ${ }^{41}$ On day 36 , mice were sacrificed and splenic responses assessed by IFN $\gamma$ ELISpot analysis. All vaccines, including the p.DOM control, induced a significant response to the $\mathrm{p} 30$ peptide confirming the integrity, in vivo expression and immunogenicity of the DNA vaccine protein products (Figure 2A-D). Furthermore, $100 \%$ of HHD mice immunized with p.DOM-WT1.37 or p.DOM-WT1.126, and 75\% of mice immunized with p.DOM-WT1.235, induced significant numbers of WT1-peptide specific IFN $\gamma$-secreting $\mathrm{T}$ cells detectable directly ex vivo (Figure 2A-C). $\mathrm{CD}^{+}$T-cell responses to WT1.235 were notably lower than responses to either of the other two WT1-peptide vaccines although these were significantly above background levels ( $p=0.005$, two-tailed Mann-Whitney U-test). As expected, the control p.DOM vaccine failed to induce any significant WT1-specific responses (Figure 2D). Encouragingly, the frequency of T cells specific for the WT1.37 peptide, which has not before been tested in any vaccination strategy, was comparable with that elicited to the WT1.126 epitope following vaccination (Figure 2A-B). We also noted that $\mathrm{T}$ cells responsive to the WT1.37 epitope 
exhibited no decrease in the frequency of responding cells when incubated with $10 \mathrm{nM}$ rather than $1 \mu \mathrm{M}$ peptide (Figure 2A). Further analysis of the WT1.37-specific response over a range of peptide concentrations confirmed that these $\mathrm{T}$ cells continue to respond to peptide at concentrations $\sim 50$-fold lower than WT1.126-specific cells (Figure 2E)

One question concerning vaccine design was the comparative performance of the peptide immunogen when delivered via DNA or as an exogenous peptide plus IFA. This was tested using peptide WT1.126, with a source of T-cell help for the exogenous peptide provided by co-injection of the PADRE peptide. Priming of $\mathrm{CD}^{+}$T-cell responses was clearly superior when using DNA delivery with $\sim 9$-fold higher levels of IFN $\gamma$-producing T cells detectable at day 10 ( $p=0.0124$ two-tailed t-test) (Figure $2 \mathrm{~F}$ ). Levels of CD $4^{+}$T-cell help against either $\mathrm{p} 30$ (DNA vaccine) or PADRE (peptide vaccine) appeared adequate in both cases (Figure 2F).

p.DOM-WT1 vaccines induce WT1-specific cytotoxic T lymphocytes

To evaluate the cytotoxic activity and peptide specificity of WT1-specific T cells induced by DNA vaccination, splenocytes from immunized mice were re-stimulated in vitro and their lytic ability tested in a ${ }^{51} \mathrm{Cr}$-release assay. CTL from mice immunized with each of the p.DOM-WT1 vaccines demonstrated significant lysis of peptide-pulsed target cells, demonstrating the functionality of WT1-specific T cells induced by pDOM-WT1 vaccination (Figure 3A-C). Lysis was not observed against target cells pulsed with an irrelevant peptide (data not shown)

To ensure that all three epitopes are naturally processed and presented by tumor cells, vaccine-induced $\mathrm{CD}^{+} \mathrm{T}$ cells were tested for their ability to lyse human leukemia cells endogenously expressing WT1 and transfected with the chimeric HLA-A2 (HHD). T cells 
specific for each individual peptide lysed human target cells expressing both WT1 and HHD, but not those expressing only HHD or WT1, demonstrating their ability to kill human tumors (Figure 3A-C). In addition, WT1.126-specific T cells induced lysis of target cells expressing HLA-A2 and WT1 in the absence of the HHD molecule (data not shown), indicating lytic activity independent of CD8.

\section{WT1-specific CD ${ }^{+}$T cells do not inhibit hematopoietic colony formation}

In light of the ability of our DNA vaccine approach to induce WT1-specific T cells, we sought to investigate whether vaccination causes damage to hematopoietic precursor cells known to express WT1. ${ }^{11}$ HHD mice were vaccinated twice with one of the three p.DOM-WT1 vaccines, with control p.DOM or were left unimmunized prior to analysis of hematopoietic stem cell frequency in the bone marrow. Ex vivo ELISpot analyses of splenic lymphocytes were performed concurrently and only mice in which a WT1-specific T-cell response was evident were evaluated (data not shown). There was no difference between the frequencies of hematopoietic stem cells (either of the granulocyte-monocyte (CFU-GM; Figure 4A) or erythroid (BFU-E; Figure 4B) lineages) present in mice vaccinated with any of the p.DOMWT1 DNA vaccines, compared with either p.DOM recipients or unimmunised mice, showing that induction of $\mathrm{CD}^{+} \mathrm{T}$ cells against WT1 does not lead to detectable loss of hematopoietic stem cells

\section{Human WT1-specific CTL can be expanded from healthy donors}

Confirming that a T-cell repertoire specific for these same peptides exists in humans, ${ }^{15 ; 16 ; 44}$ WT1-specific $\mathrm{CD}^{+} \mathrm{T}$ cells were successfully expanded from a total of 5 of 10 healthy HLA$\mathrm{A}^{+}$donor PBMC. Briefly, cells were exposed to autologous DC pulsed with one of the WT1-derived peptides and were then re-stimulated at 10-day intervals with autologous 
monocytes pulsed with the corresponding peptide. Rezvani et al. (2005) previously reported, using IFN- $\gamma$ mRNA production in response to peptide stimulation, that $\mathrm{T}$ cells specific for WT1.126 or WT1.235 could be identified in 3 of 12 healthy individuals. ${ }^{15}$ We have used pentamer staining and functional assays to show that 1 of 5 , and 2 of 6 , healthy donors had a repertoire of T cells specific for WT1.126 and WT1.235 respectively (Figure 5 and data not shown), broadly reflecting the frequency of responders identified previously. ${ }^{15}$ WT1.126expanded cells did not bind to the WT1.235 pentamer and vice versa, confirming the specificity of the multimers used (Figure 5A). CTL specific for the WT1.37 epitope could not be quantified in this way as HLA-A*0201/WT1.37 pentamers could not be made.

To determine whether WT1.37-specific T cells were expanded and to investigate the functionality of WT1-specific T cells, particularly those specific for WT1.235 and WT1.37 whose lytic ability has not been previously reported, CTL lines were established and used in ${ }^{51} \mathrm{Cr}$-release assays. $\mathrm{T}$ cells of all three specificities were able to mediate lysis against peptide-loaded target cells (Figure 5B-D). Peptide-specific cytotoxic responses were detected in 3 of 7 WT1.37 cultures; for WT1.126 and WT1.235 only cultures in which specific cells were detected by pentamer staining exhibited significant levels of lysis.

Human WT1.37-specific CTL kill WT1-expressing tumor cell lines and primary leukemia cells in an $H L A-A^{*} 0201-$ restricted manner.

Natural processing and presentation of WT1.126 and WT1.235 by HLA-A*0201 and WT1expressing leukemic cells has been reported. ${ }^{19 ; 21 ; 22 ; 45}$ However, it is not known whether this is similarly the case for the WT1.37 epitope, to which particularly avid T cells exist in vaccinated transgenic mice (Figure 2E) and in healthy humans. ${ }^{15}$ We therefore chose to focus on human WT1.37-specific T cells and evaluated their ability to kill human tumor cell lines 
(697 and RS 4,11) and primary tumor cells expressing both HLA-A*0201 and WT1. Our data show that WT1.37-specific CTL efficiently lyse both the 697 and the RS 4,11 cell lines and 4 of 4 primary tumor cell samples from HLA-A*0201 ${ }^{+}$patients with acute leukaemia (either ALL (patient I) or AML (patients II-IV)) (Figure 6A). A significant proportion of the observed lysis against both cell lines and the $2 \mathrm{WT} 1^{+} \mathrm{HLA}-\mathrm{A}^{*} 0201^{+}$primary AML tumors tested, was HLA-class I-restricted, underscoring the specificity of the effector T cells (Figure 6B). Specificity was further confirmed by the absence of lysis against WT1-expressing, yet HLA-A*0201 negative, primary tumor cells (patients V and VI) (Figure 6C). These data clearly show that the WT1.37 epitope is processed and presented by HLA-A*0201-positive and WT1-expressing human tumor cell lines and primary tumor cells from patients with acute leukemia.

The WT1.37 peptide is processed and presented similarly by tumors and following DNA vaccination

Finally, human-derived WT1.37-specific CTL were used to verify that WT1 peptides are processed and presented by human cells expressing the DNA fusion vaccine product. To this end, a human B-cell line, VAL (expressing HLA-A*0201 but not WT1), was transfected either with p.DOM-WT1.37, or with the control plasmids p.DOM or p.EGFP. WT1.37specific CTL were able to specifically kill these antigen-presenting cells transfected with pDOM-WT1.37, at levels higher than those transfected with control plasmids, confirming that the protein product of pDOM-WT1.37 is expressed, and the WT1.37 epitope presented, by human cells (Figure 7). 


\section{DISCUSSION}

In this report we made use of humanized mice to test our DNA vaccination approach against the leukemia-associated antigen WT1. The similar sequence and distribution pattern of WT1 in mice and humans strongly imply that the extent of WT1-specific T-cell tolerance in the two species is likely to be comparable. By using mice transgenic for a chimeric form of HLA-A2, we have been able to model the ability of three epitope-specific DNA vaccines to induce HLA-A2-restricted $\mathrm{CD}^{+}$T-cell responses against WT1.

Previous studies have revealed that vaccinating wild type C57BL/6 mice with peptide-pulsed splenocytes, ${ }^{46}$ or peptides in adjuvant, ${ }^{47: 48}$ can induce T-cell responses against WT1.126 in vivo. In this case, the response was restricted by mouse $\mathrm{H}-2 \mathrm{D}^{\mathrm{b}}$ class I molecules ${ }^{46 ; 47}$ indicating that this peptide can bind to both human and mouse MHC class I molecules, but diminishing the relevance to human responses. In contrast, we have made use of HHD transgenic mice expressing only human HLA-A2 MHC class I chimeric molecules. Clearly, DNA vaccination can induce functional $T$ cells to three clinically relevant HLA-A*0201restricted epitopes, WT1.126, WT1.235 and WT1.37, in vivo. The ability of DNA delivery to prime $\mathrm{CD}^{+}$T-cell responses against WT1.126 was found to be $\sim 9$-fold higher than that of exogenous peptide plus adjuvant and a source of T-cell help. While further comparisons are required, this suggests an advantage for peptide delivery via DNA. Importantly, the CTL generated also lysed human leukemia cells expressing WT1 from an endogenous source. To link pre-clinical findings to the clinic, we have studied the natural repertoire of human WT1specific $\mathrm{T}$ cells with similar specificity, to ensure that there is a potential repertoire available for expansion by vaccination. 
Using an assay for IFN $\gamma$ mRNA, Rezvani et al. (2005) have previously detected $\mathrm{CD}^{+} \mathrm{T}$ cells specific for each of the three epitopes, WT1.37, WT1.126 and WT1.235, in the blood of patients with leukemia, ${ }^{15}$ showing that a repertoire of WT1-reactive cells persists in cancer patients. Notably, human T cells with specificity for WT1.37 were of approximately 2.5 -fold greater avidity than WT1.126-reactive cells, ${ }^{15}$ mirroring our findings in p.DOM-WT1.37vaccinated HHD mice and underscoring the relevance of HHD mice for pre-clinical modelling. For WT1.37, we have taken this a step further in two ways to show first, that a DNA vaccine can induce high levels of avid CTLs in a setting where there is natural expression of WT1 and therefore the potential for immune tolerance, and, second, that WT1.37 is processed and presented naturally by primary tumor cells.

Although $\mathrm{CD}^{+} \mathrm{T}$ cells against all three peptides can kill WT1-positive targets, there was no evidence for loss of normal stem cells. Previous studies of WT1 responses in wild-type mice also failed to find any evidence of autoimmune disease ${ }^{46 ; 48}$ and thus far only mild adverse effects have been reported in patients immunized against WT1.126 or WT1.235. ${ }^{25 ; 26}$ Our data additionally suggest that this might similarly be the case following clinical vaccination against the WT1.37 epitope.

To date WT1.126, WT1.235 and a modified version of WT1.235 (CYTWNQMNL), designed to improve binding to HLA-A $* 2402,{ }^{49}$ are being evaluated in clinical trials for patients with acute leukaemia. ${ }^{23 ; 25 ; 26 ; 50}$ In each case peptide is injected with adjuvant and some success has been reported, with a recent trial showing specific responses after just one injection ${ }^{50}$. However, one problem for peptide vaccines is the failure to provide $\mathrm{CD} 4^{+} \mathrm{T}$-cell help, known to be essential for induction of effective $\mathrm{CD}^{+} \mathrm{T}$-cell memory. ${ }^{51-53}$ 
Delivery via $\mathrm{DC}$ is an alternative strategy to activate $\mathrm{CD}^{+} \mathrm{T}$ cell responses and could be attractive for AML, especially since AML-derived DC can express leukemia-associated antigens. $^{54}$ However, WT1 expression appears to be down-regulated in AML-DC arguing against the approach for this antigen. ${ }^{54}$ We have chosen to use active vaccination with our p.DOM-peptide DNA vaccines specifically designed to provide $\mathrm{CD} 4^{+} \mathrm{T}$ cell help. Indeed our previous work has confirmed that $\mathrm{CD} 4^{+} \mathrm{T}$-helper cells expanded from the non-tolerized tetanus-specific repertoire are critical for effective priming of $\mathrm{CD}^{+} \mathrm{T}$ cells in vivo following p.DOM-peptide immunization. ${ }^{31}$ Importantly, we have previously shown in an alternative model that our DNA vaccine design can overcome tolerance in mice. ${ }^{36}$ This is likely to be an issue in patients exposed to high loads of leukemic cells. Other strategies exist to circumvent this toleragenic pressure on the repertoire, including the generation of allogeneic CTL against mismatched MHC/WT1 peptide complexes. Thus, allogeneic and lytic HLA-A*0201' CTLs are generated against HLA-A*0201/WT1.126 or HLA-A*0201/WT1.235 complexes in vitro. ${ }^{19 ; 21}$ This adoptive therapy approach has to face destruction of the transferred cells and to avoid this, genes encoding the TCR expressed by these allogeneic CTLs are being transduced into autologous $\mathrm{T}$ cells with the intention of subsequent adoptive transfer into patients. $^{55 ; 56}$

Although successful vaccination has the advantage of providing continuous surveillance of emergent tumor, a strong immune response in the clinic is required. It is now evident that performance of DNA vaccines in larger animals, including human subjects, is not optimal. The reason for this appears to be the delivery system which, for intramuscular injection, uses relatively large volumes for mice. Since these cannot be scaled up for human subjects, an alternative strategy to increase transfection rate and inflammation at the site has been sought. One approach is the technique of electroporation which amplifies responses dramatically, especially at boosting. ${ }^{41}$ This exciting technology is now undergoing clinical testing in our institution and several prostate cancer patients have received p.DOM-peptide DNA vaccines delivered in this way with no serious adverse effects. 
One criticism of using epitope-specific vaccines is that tumors may escape immune detection by losing epitope expression. To cover this possibility, DNA vaccines encoding the three promising HLA-A*0201-binding epitopes, ideally injected at different sites to avoid competition, could be used to induce a wide range of CTL. While encoding a longer sequence from WT1 may achieve this, our previous work has shown that encoding long tumor antigen sequences may compromise epitope presentation. ${ }^{35}$ In addition, immunodominance predicts that immune responses will focus on one epitope following subsequent booster injections. $^{57}$

In summary, our data reveal that a repertoire of $\mathrm{T}$ cells with specificity for the tumorassociated antigen, WT1, exists in humans and humanized transgenic mice and the preclinical model has revealed a DNA vaccine strategy to induce or expand specific CTL. This sets the scene for clinical testing of these safe, specific DNA vaccines in cancer patients with HLA-A*0201 $1^{+}$and $\mathrm{WT1}^{+}$tumour cells, in settings where there is a need to suppress emergence of residual tumor.

\section{ACKNOWLEDGEMENTS}

This work was supported by the French Association for Cancer Research, grant 3257 (C.C., J.M., M-H.D-L., V.M-F.), the Fondation pour la Recherche Médicale (C.C.), the Leukaemia Research Fund, grant 0306 (S.L.B., J.R. and F.K.S.) and Cancer Research U.K. grant C7643/A3748 (G.E.V). The authors would like to thank Valérie Guislain (AP-HP, Hôpital Henri Mondor, Service d'Immunologie biologique, France) for help with induction of human WT1-specific CTL, Dr Iacob Mathiesen of Inovio AS (San Diego, CA) for supplying the electroporation pulse generator and associated software and Sandrine Machane (Paris, France) and staff in the biomedical research facility (Southampton, U.K.) for animal care. 
Authorship contributions: C.C. and S.L.B. conceived, designed and performed the research, analysed data and wrote the report, J.M. assisted with experiments and processed samples, H.R. and M.K. supplied clinical samples, G.E.V. provided essential novel reagents, V.M-F, JP.F and H.J.S. provided intellectual support, J.R. conceived and supervised the study, M-H.DL. and F.K.S conceived and supervised the study and wrote the report. C.C. and S.L.B. contributed equally to this study. Conflict of interest disclosure: Several of the authors (J.R., F.K.S.) hold a patent relating to the DNA vaccine design described in the article and have declared a financial interest in a company which holds an exclusive licence relating to this design. 


\section{REFERENCES}

1. Kolb HJ, Schattenberg A, Goldman JM et al. Graft-versus-leukemia effect of donor lymphocyte transfusions in marrow grafted patients. Blood 1995;86:2041-2050.

2. Greiner J, Dohner H, Schmitt M. Cancer vaccines for patients with acute myeloid leukemia--definition of leukemia-associated antigens and current clinical protocols targeting these antigens. Haematologica 2006;91:1653-1661.

3. Oji Y, Miyoshi S, Maeda H et al. Overexpression of the Wilms' tumor gene WT1 in de novo lung cancers. Int.J.Cancer 2002;100:297-303.

4. Inoue $\mathrm{K}$, Ogawa $\mathrm{H}$, Sonoda $\mathrm{Y}$ et al. Aberrant overexpression of the Wilms tumor gene (WT1) in human leukemia. Blood 1997;89:1405-1412.

5. Koesters R, Linnebacher M, Coy JF et al. WT1 is a tumor-associated antigen in colon cancer that can be recognized by in vitro stimulated cytotoxic $\mathrm{T}$ cells. Int.J.Cancer 2004; 109:385-392.

6. Oji Y, Yamamoto H, Nomura M et al. Overexpression of the Wilms' tumor gene WT1 in colorectal adenocarcinoma. Cancer Sci. 2003;94:712-717.

7. Yamagami $\mathrm{T}$, Sugiyama H, Inoue K et al. Growth inhibition of human leukemic cells by WT1 (Wilms tumor gene) antisense oligodeoxynucleotides: implications for the involvement of WT1 in leukemogenesis. Blood 1996;87:2878-2884.

8. Rauscher FJ, III. The WT1 Wilms tumor gene product: a developmentally regulated transcription factor in the kidney that functions as a tumor suppressor. FASEB J. $1993 ; 7: 896-903$ 
9. Lee SB, Haber DA. Wilms tumor and the WT1 gene. Exp.Cell Res. 2001;264:74-99.

10. Hosen N, Sonoda Y, Oji Y et al. Very low frequencies of human normal CD34+ haematopoietic progenitor cells express the Wilms' tumour gene WT1 at levels similar to those in leukaemia cells. Br.J.Haematol. 2002;116:409-420.

11. Fraizer GC, Patmasiriwat P, Zhang X, Saunders GF. Expression of the tumor suppressor gene WT1 in both human and mouse bone marrow. Blood 1995;86:4704-4706.

12. Gaiger A, Carter L, Greinix H et al. WT1-specific serum antibodies in patients with leukemia. Clin.Cancer Res. 2001;7:761s-765s

13. Wu F, Oka Y, Tsuboi A et al. Th1-biased humoral immune responses against Wilms tumor gene WT1 product in the patients with hematopoietic malignancies. Leukemia $2005 ; 19: 268-274$

14. Elisseeva OA, Oka Y, Tsuboi A et al. Humoral immune responses against Wilms tumor gene WT1 product in patients with hematopoietic malignancies. Blood 2002;99:32723279 .

15. Rezvani K, Brenchley JM, Price DA et al. T-cell responses directed against multiple HLA-A*0201-restricted epitopes derived from Wilms' tumor 1 protein in patients with leukemia and healthy donors: identification, quantification, and characterization. Clin.Cancer Res. 2005;11:8799-8807.

16. Scheibenbogen $\mathrm{C}$, Letsch A, Thiel E et al. CD8 T-cell responses to Wilms tumor gene product WT1 and proteinase 3 in patients with acute myeloid leukemia. Blood $2002 ; 100: 2132-2137$. 
17. Gannage M, Abel M, Michallet AS et al. Ex vivo characterization of multiepitopic tumorspecific CD8 T cells in patients with chronic myeloid leukemia: implications for vaccine development and adoptive cellular immunotherapy. J.Immunol. 2005;174:8210-8218.

18. Rezvani K, Yong AS, Savani BN et al. Graft-versus-leukemia effects associated with detectable Wilms tumor-1 specific T lymphocytes after allogeneic stem-cell transplantation for acute lymphoblastic leukemia. Blood 2007;110:1924-1932.

19. Gao L, Bellantuono I, Elsasser A et al. Selective elimination of leukemic CD34(+) progenitor cells by cytotoxic T lymphocytes specific for WT1. Blood 2000;95:21982203

20. Ohminami H, Yasukawa M, Fujita S. HLA class I-restricted lysis of leukemia cells by a CD8(+) cytotoxic T-lymphocyte clone specific for WT1 peptide. Blood 2000;95:286293.

21. Bellantuono I, Gao L, Parry S et al. Two distinct HLA-A0201-presented epitopes of the Wilms tumor antigen 1 can function as targets for leukemia-reactive CTL. Blood $2002 ; 100: 3835-3837$

22. Doubrovina ES, Doubrovin MM, Lee S et al. In vitro stimulation with WT1 peptideloaded Epstein-Barr virus-positive B cells elicits high frequencies of WT1 peptidespecific $\mathrm{T}$ cells with in vitro and in vivo tumoricidal activity. Clin.Cancer Res. 2004; 10:7207-7219.

23. Mailander V, Scheibenbogen C, Thiel E et al. Complete remission in a patient with recurrent acute myeloid leukemia induced by vaccination with WT1 peptide in the absence of hematological or renal toxicity. Leukemia 2004;18:165-166. 
24. Smithgall M, Misher L, Spies G, Cheever MA, Gaiger A. Identification of a novel WT1 HLA-A*0201-restricted CTL epitope using whole gene in vitro priming. [abstract]. American Society of Hematology Meeting 2001;

25. Oka Y, Tsuboi A, Taguchi T et al. Induction of WT1 (Wilms' tumor gene)-specific cytotoxic T lymphocytes by WT1 peptide vaccine and the resultant cancer regression. Proc.Natl.Acad.Sci.U.S.A 2004;101:13885-13890.

26. Keilholz U, Menssen HD, Gaiger A et al. Wilms' tumour gene 1 (WT1) in human neoplasia. Leukemia 2005;19:1318-1323.

27. Spellerberg MB, Zhu D, Thompsett A et al. DNA vaccines against lymphoma: promotion of anti-idiotypic antibody responses induced by single chain Fv genes by fusion to tetanus toxin fragment C. J.Immunol. 1997;159:1885-1892.

28. King CA, Spellerberg MB, Zhu D et al. DNA vaccines with single-chain Fv fused to fragment $\mathrm{C}$ of tetanus toxin induce protective immunity against lymphoma and myeloma. Nat.Med. 1998;4:1281-1286.

29. Stevenson FK, Ottensmeier $\mathrm{CH}$, Johnson $\mathrm{P}$ et al. DNA vaccines to attack cancer. Proc.Natl.Acad.Sci.U.S.A 2004;101 Suppl 2:14646-14652.

30. Stevenson FK, Rice J, Zhu D. Tumor vaccines. Adv.Immunol. 2004;82:49-103.

31. Radcliffe JN, Roddick JS, Friedmann PS, Stevenson FK, Thirdborough SM. Prime-boost with alternating DNA vaccines designed to engage different antigen presentation pathways generates high frequencies of peptide-specific CD8+ T cells. J.Immunol. 2006; 177:6626-6633. 
32. Fairweather NF, Lyness VA. The complete nucleotide sequence of tetanus toxin. Nucleic Acids Res. 1986;14:7809-7812.

33. Demotz S, Matricardi P, Lanzavecchia A, Corradin G. A novel and simple procedure for determining T cell epitopes in protein antigens. J.Immunol.Methods 1989;122:67-72.

34. Rice J, Buchan S, Stevenson FK. Critical components of a DNA fusion vaccine able to induce protective cytotoxic $\mathrm{T}$ cells against a single epitope of a tumor antigen. J.Immunol. 2002;169:3908-3913.

35. Rice J, Elliott T, Buchan S, Stevenson FK. DNA fusion vaccine designed to induce cytotoxic $\mathrm{T}$ cell responses against defined peptide motifs: implications for cancer vaccines. J.Immunol. 2001;167:1558-1565.

36. Rice J, Buchan S, Dewchand H, Simpson E, Stevenson FK. DNA fusion vaccines induce targeted epitope-specific CTLs against minor histocompatibility antigens from a normal or tolerized repertoire. J.Immunol. 2004;173:4492-4499.

37. Pascolo S, Bervas N, Ure JM et al. HLA-A2.1-restricted education and cytolytic activity of CD8(+) T lymphocytes from beta2 microglobulin (beta2m) HLA-A2.1 monochain transgenic H-2Db beta2m double knockout mice. J.Exp.Med. 1997;185:2043-2051.

38. Rice J, Ottensmeier CH, Stevenson FK. DNA vaccines: precision tools for activating effective immunity against cancer. Nat.Rev.Cancer 2008;8:108-120.

39. Rauscher FJ, III. The WT1 Wilms tumor gene product: a developmentally regulated transcription factor in the kidney that functions as a tumor suppressor. FASEB J. $1993 ; 7: 896-903$ 
40. Alexander J, Sidney J, Southwood S et al. Development of high potency universal DRrestricted helper epitopes by modification of high affinity DR-blocking peptides. Immunity. 1994;1:751-761.

41. Buchan S, Gronevik E, Mathiesen I et al. Electroporation as a "prime/boost" strategy for naked DNA vaccination against a tumor antigen. J.Immunol. 2005;174:6292-6298.

42. Rice J, King CA, Spellerberg MB, Fairweather N, Stevenson FK. Manipulation of pathogen-derived genes to influence antigen presentation via DNA vaccines. Vaccine 1999; 17:3030-3038.

43. Ho WY, Nguyen HN, Wolfl M, Kuball J, Greenberg PD. In vitro methods for generating CD8+ T-cell clones for immunotherapy from the naive repertoire. J.Immunol.Methods $2006 ; 310: 40-52$

44. Rezvani K, Grube M, Brenchley JM et al. Functional leukemia-associated antigenspecific memory CD8+ T cells exist in healthy individuals and in patients with chronic myelogenous leukemia before and after stem cell transplantation. Blood 2003;102:28922900.

45. Savage $\mathrm{P}$, Gao L, Vento K et al. Use of B cell-bound HLA-A2 class I monomers to generate high-avidity, allo-restricted CTLs against the leukemia-associated protein Wilms tumor antigen. Blood 2004;103:4613-4615.

46. Oka Y, Udaka K, Tsuboi A et al. Cancer immunotherapy targeting Wilms' tumor gene WT1 product. J.Immunol. 2000;164:1873-1880.

47. Gaiger A, Reese V, Disis ML, Cheever MA. Immunity to WT1 in the animal model and in patients with acute myeloid leukemia. Blood 2000;96:1480-1489. 
48. Nakajima H, Kawasaki K, Oka Y et al. WT1 peptide vaccination combined with BCGCWS is more efficient for tumor eradication than WT1 peptide vaccination alone. Cancer Immunol.Immunother. 2004;53:617-624.

49. Tsuboi A, Oka Y, Udaka K et al. Enhanced induction of human WT1-specific cytotoxic T lymphocytes with a 9-mer WT1 peptide modified at HLA-A*2402-binding residues. Cancer Immunol.Immunother. 2002;51:614-620.

50. Rezvani K, Yong AS, Mielke S et al. Leukemia-associated antigen specific T-cell responses following combined PR1 and WT1 peptide vaccination in patients with myeloid malignancies. Blood 2007;111:236-242.

51. Sun JC, Bevan MJ. Defective CD8 T cell memory following acute infection without CD4 T cell help. Science 2003;300:339-342.

52. Janssen EM, Lemmens EE, Wolfe $\mathrm{T}$ et al. CD4+ $\mathrm{T}$ cells are required for secondary expansion and memory in CD8+ T lymphocytes. Nature 2003;421:852-856.

53. Shedlock DJ, Shen $\mathrm{H}$. Requirement for CD4 T cell help in generating functional CD8 T cell memory. Science 2003;300:337-339.

54. Li L, Reinhardt P, Schmitt A et al. Dendritic cells generated from acute myeloid leukemia $(\mathrm{AML})$ blasts maintain the expression of immunogenic leukemia associated antigens. Cancer Immunol.Immunother. 2005;54:685-693.

55. Xue S, Gillmore R, Downs A et al. Exploiting $\mathrm{T}$ cell receptor genes for cancer immunotherapy. Clin.Exp.Immunol. 2005;139:167-172.

56. Xue SA, Gao L, Hart D et al. Elimination of human leukemia cells in NOD/SCID mice by WT1-TCR gene-transduced human T cells. Blood 2005;106:3062-3067. 
57. Palmowski MJ, Choi EM, Hermans IF et al. Competition between CTL narrows the immune response induced by prime-boost vaccination protocols. J.Immunol. $2002 ; 168: 4391-4398$. 


\section{FIGURE LEGENDS}

Figure 1. Schematic representation of DNA vaccines. All DNA vaccines encode the leader sequence of the $\mathrm{V}_{\mathrm{H}}$ heavy chain gene from the $\mathrm{BCL}_{1}$ lymphoma upstream of sequence encoding the first domain of Fragment $\mathrm{C}(\mathrm{FrC})$ of tetanus toxin $\left(\mathrm{TT}_{865-1120}\right)$ which contains a promiscuous MHC II-binding sequence, p30. The control vaccine p.DOM contains no additional sequence while p.DOM-WT1.37 additionally encodes VLDFAPPGA (WT1 $137-45)$, p.DOM-WT1.126 additionally encodes RMFPNAPYL $\left(W T 1_{126-134}\right)$ and p.DOM-WT1.235 encodes CMTWNQMNL (WT1 $\left.1_{235-243}\right)$ downstream of the FrC sequence.

Figure 2. DNA vaccination induces WT1-specific IFN- $\gamma$-secreting $T$ cells in HHD mice. HHD mice were vaccinated with either (A) p.DOM-WT1.37 (n=7), (B) p.DOM-WT1.126 $(\mathrm{n}=8),(\mathrm{C})$ p.DOM-WT1.235 $(\mathrm{n}=12)$ or (D) p.DOM $(\mathrm{n}=20)$, and were boosted 28 days later with the same vaccine delivered using in vivo electroporation. On day 36 splenic lymphocytes were harvested by density centrifugation of spleen cells and the frequency of specific $\mathrm{T}$ cells assessed by IFN $\gamma$ ELISpot following a brief incubation alone (no pep), with an irrelevant peptide (irr pep; $10^{-6} \mathrm{M}$ ) with p30 peptide $\left(10^{-6} \mathrm{M}\right.$ ) or with the relevant WT1 peptide $\left(10^{-6} \mathrm{M}\right.$ or $\left.10^{-8} \mathrm{M}\right)$. Data are expressed as the number of spot-forming cells (SFCs) per million lymphocytes and are a combination of 2 of 2 experiments with similar results; group means are represented by a horizontal bar. Responses were considered significant if the frequency of IFN- $\gamma$-secreting cells was more than double the frequency detected in wells without peptide. (E) Lymphocytes from mice vaccinated with p.DOM-WT1.37 $(\mathrm{n}=4)$ or p.DOM-WT1.126 $(\mathrm{n}=9)$ were incubated with a range of peptide concentrations and the frequency of specific cells assessed by ELISpot analysis as before. Data are shown as the mean percentage of the maximum obtained for each mouse with the standard error of the mean indicated. A non-linear line of best fit was plotted using GraphPad Prism 4 software. 
(F) HHD mice were injected with DNA vaccine (p.DOM-WT1.126; DNA) or with peptide vaccine (WT1.126 peptide in IFA mixed with PADRE peptide: peptide). Lymphocytes were harvested on day 10 and the frequency of vaccine-specific T cells assessed by IFN $\gamma$ ELISpot following a brief incubation alone (no pep), with the Th peptides p30 or PADRE $\left(10^{-6} \mathrm{M}\right)$ or with the WT1.126 peptide $\left(10^{-6} \mathrm{M}\right)$. Group means are represented by a horizontal bar.

Figure 3. WT1-specific $T$ cells induced by DNA vaccination are peptide specific and kill target cells presenting WT1. Splenocyte cultures from individual mice previously immunized with either (A) p.DOM-WT1.37, (B) p.DOM-WT1.126 or (C) p.DOM-WT1.235 were established by stimulation in vitro for two weeks before assessing cytotoxicity by ${ }^{51} \mathrm{Cr}$ release assay. Cytotoxicity was assessed at the effector:target ratios shown, against human tumor cells endogenously expressing WT1 and stably transduced with the chimeric humanized MHC class I molecule, HHD, denoted as HHD+WT1+ (specifically, KYO-HHD (A and C) or 697-HHD (B) cells). Cell lines expressing either WT1 (HHD-WT1+) or HHD (HHD+WT1-) were included as negative controls (KYO-1 and C1RA2-HHD respectively), HHD-transduced cells pulsed with the relevant peptide were used as positive controls.

Figure 4. Vaccination with p.DOM-WT1 DNA vaccines does not lead to destruction of hematopoietic stem cells. Groups of mice were injected with the vaccines shown on days 0 and 28 (+ electroporation), or were left unimmunized. Mice were culled between days 36 and 42 and spleen and bone marrow collected. Splenocytes were used to confirm the presence of WT1-specific T cells by ELISpot; non-responding mice were excluded from analysis (data not shown). Bone marrow cells were assessed for the frequency of (A) colony-forming units granulocyte-macrophage (CFU-GM) and (B) burst-forming units-erythroid (BFU-E). Data are a pool of 3 of 3 experiments with group means and standard deviations shown. 
Figure 5. Human WT1-peptide-specific CTL can be expanded in vitro and specifically kill peptide-pulsed cells. (A) Independently in vitro expanded WT1.126 (upper row) and WT1.235-specific (lower row) $\mathrm{CD}^{+} \mathrm{T}$ cells were identified on day 31 and day 45 of culture respectively, by double-labelling using specific-HLA-A*0201/peptide-biotin labelled pentamers with streptavidin-PE and anti-CD8-PE-Cy5 labelled antibody. Negative controls were similarly stained with the opposite and irrelevant HLA-A*0201/peptide pentamer. Numbers indicate the percentage of $\mathrm{CD} 8^{+}$cells of whole culture capable of binding pentamer. On day 54 of culture, (B) WT1.37 (C) WT1.126 or (D) WT1.235-peptide-specific CD8 ${ }^{+}$T cells, were tested for their ability to lyse HLA-A*0201 autologous PHA-Blasts (B) or the VAL cell line $(C$ and $D)$ pulsed with the indicated peptides at the effector/target $(E / T)$ ratios shown. For each CTL line generated (3 WT1.37-specific, 1 WT1.126-specific and 2 WT1.235-specific) the assay was performed twice. Data were similar in each case and representative results are shown.

Figure 6. Human WT1.37-specific CTL kill WT1-expressing tumor cell lines and WT1positive primary leukemia cells in a HLA-class I-dependent manner. WT1.37-specific CTL were tested in a chromium release assay for lytic activity against (A) 697 and RS 4,11 cell lines (both $\mathrm{HLA}-\mathrm{A}^{*} 0201^{+} \mathrm{WT}^{+}$) and primary $\mathrm{WT}^{+}$leukemia cells from 4 different HLA-A*0201 $1^{+}$patients (I to IV) alone at the effector/target (E/T) ratios indicated or (B) in the presence of an antibody specific for HLA-class I (W6.32), alone (w/o Ab) or with an isotype control (+isotype) at an effector/target cell ratio of 60:1 (targets 697, RS 4,11 and sample III) or 100:1 (sample II). (C) WT1.37-specific CTL were tested for lytic activity against target cells from 2 different $\mathrm{WT}^{+}{ }^{+}$and $\mathrm{HLA}-\mathrm{A}^{*} 0201^{-}$patients (V and VI). Data are a combination 
of 2 experiments with 2 different WT1.37-specific CTL lines, differentiated by white or grey bars.

Figure 7. Human B cells transfected with p.DOM-WT1.37 present the WT1.37/HLA complex to, and are lysed by, WT1.37-specific T cells. The VAL follicular lymphoma $\left(\mathrm{HLA}-\mathrm{A}^{*} 0201^{+} \mathrm{WT}^{-}{ }^{-}\right)$cell line was transfected with p.DOM-WT1.37 or with control plasmids p.DOM or p.EGFP. Twenty-four hours later, transfectants were tested for their susceptibility to lysis by human WT1.37-specific CTL. Data shown are representative of 3 experiments performed. 


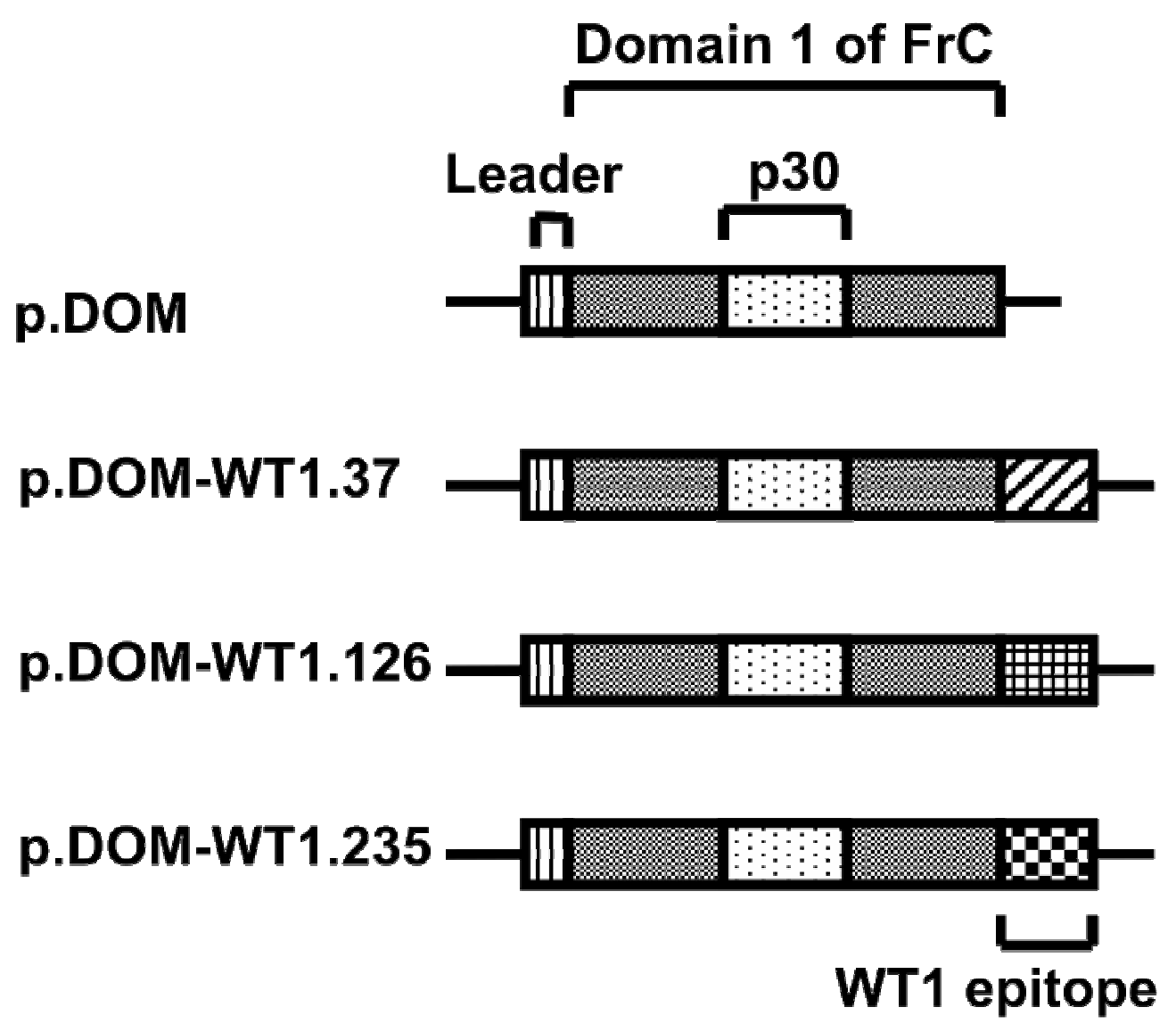

Figure 1 


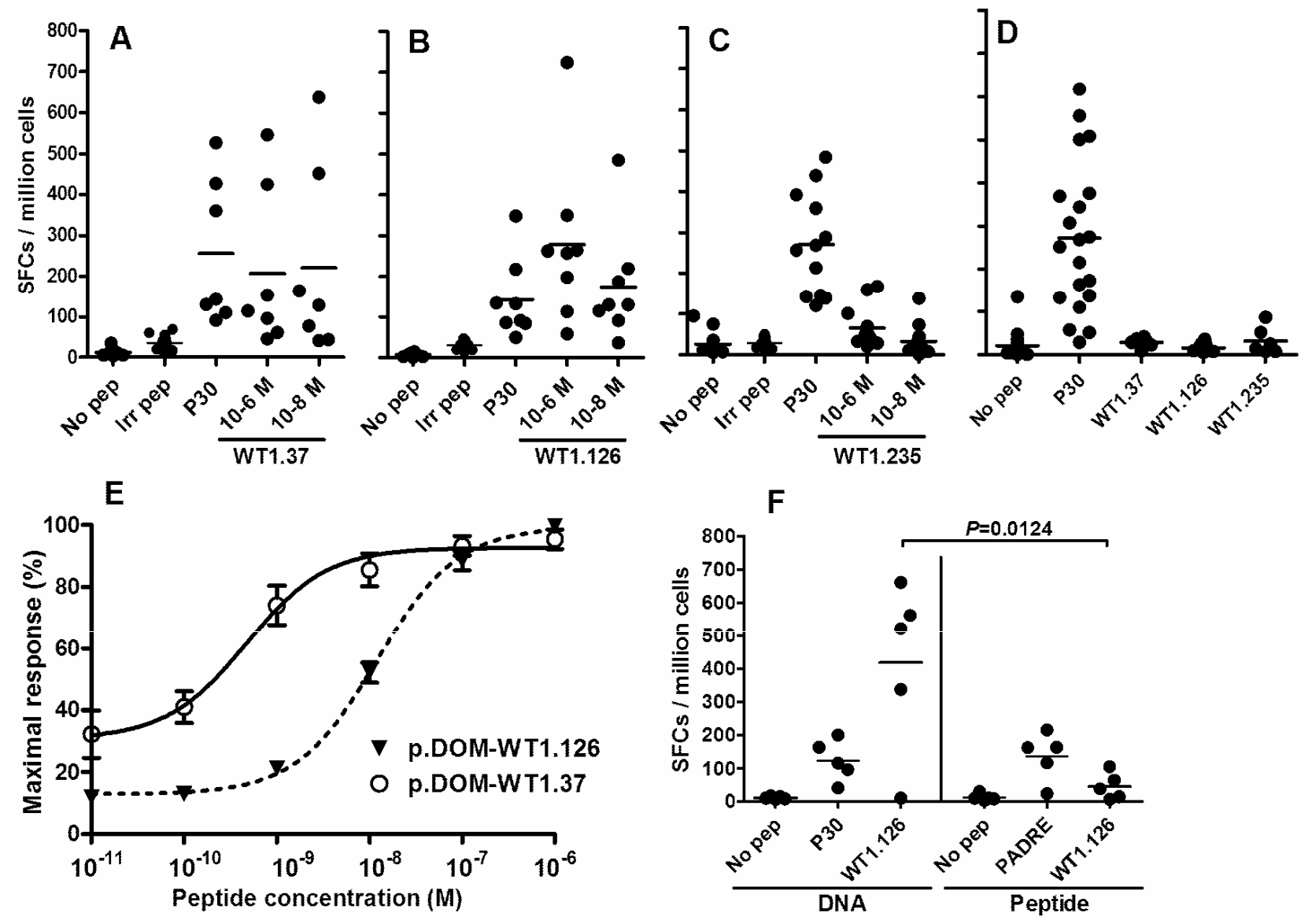

Figure 2 
A

Vaccine: p.DOM-WT1.37

Targets:

HHD-WT1+

- HHD+WT1+

- HHD+W T1-

돈 HHD + WT1.37

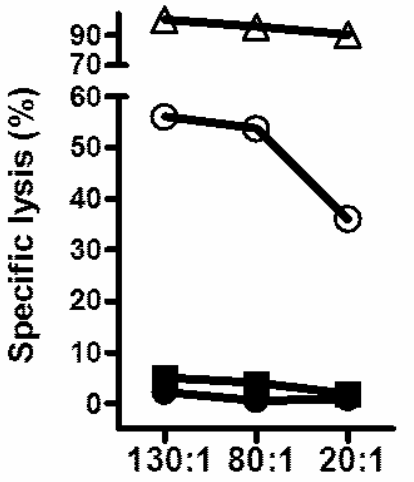

B

p.DOM-W T1.126

- HHD-W T1+

- HHD+W T1+

- HHD+W T1 -

HHD + W T1.126

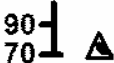

(100:1

E/T Ratio
C

p.DOM-W T1.235

- HHD-WT1+

- $\mathrm{HHD}+\mathrm{WT1}+$

$-\mathrm{HHD}+\mathrm{WT}=$

A HHD + WT1.235

${ }_{70} \mathrm{~A} \Delta$

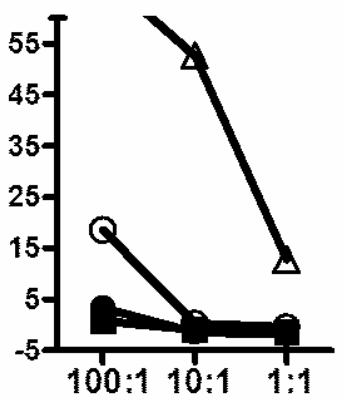

Figure 3 


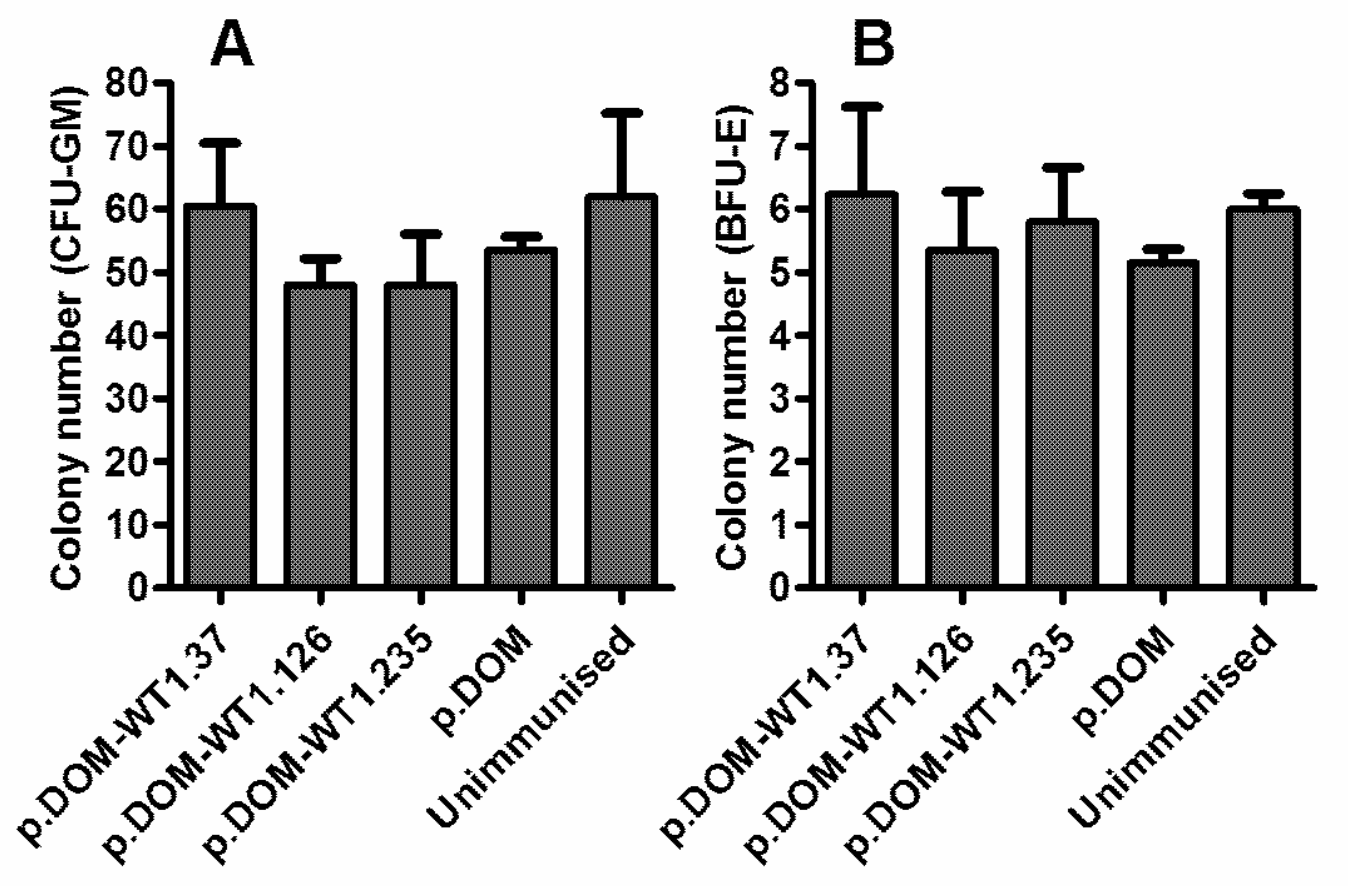

Figure 4 

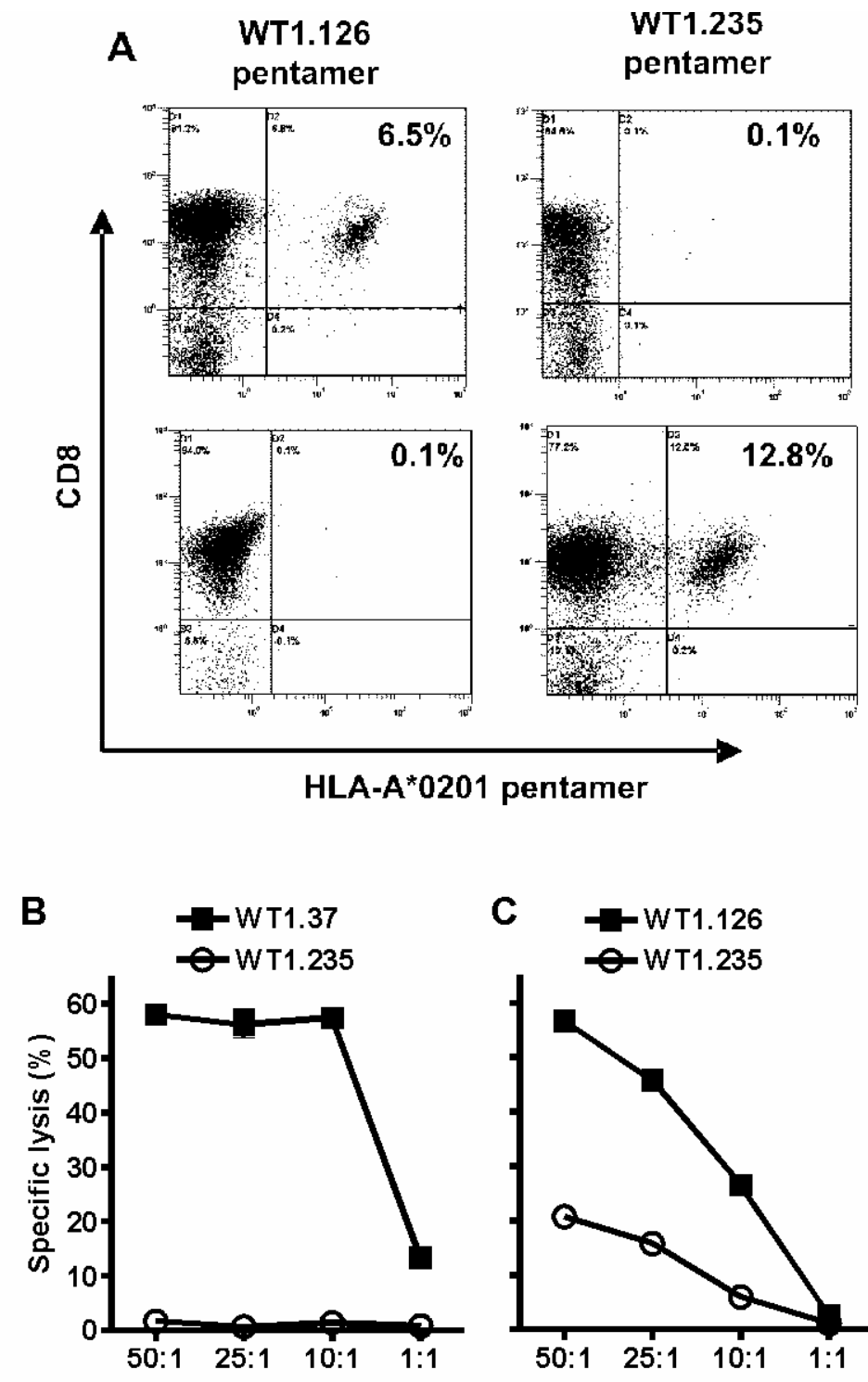

WT1.126

CTL line

WT1.235

CTL line
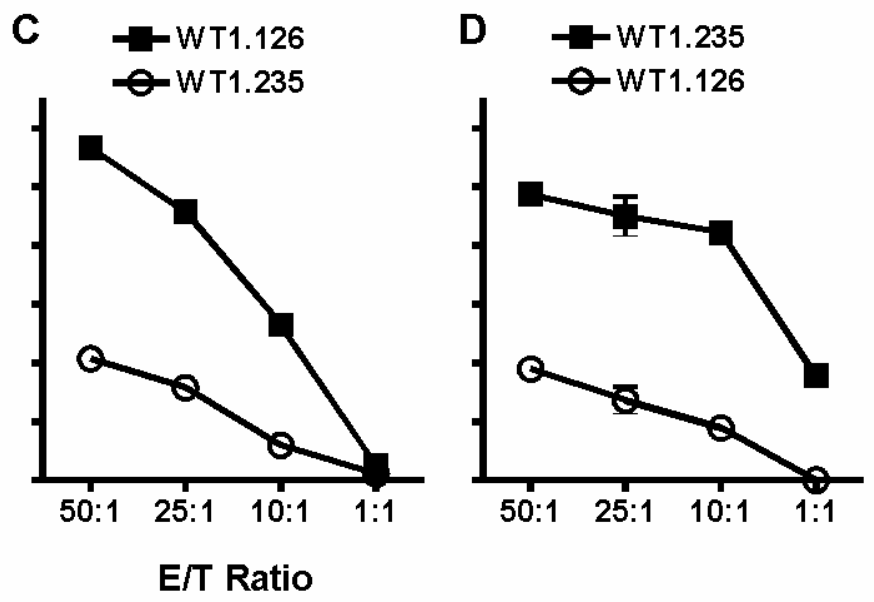

Figure 5 

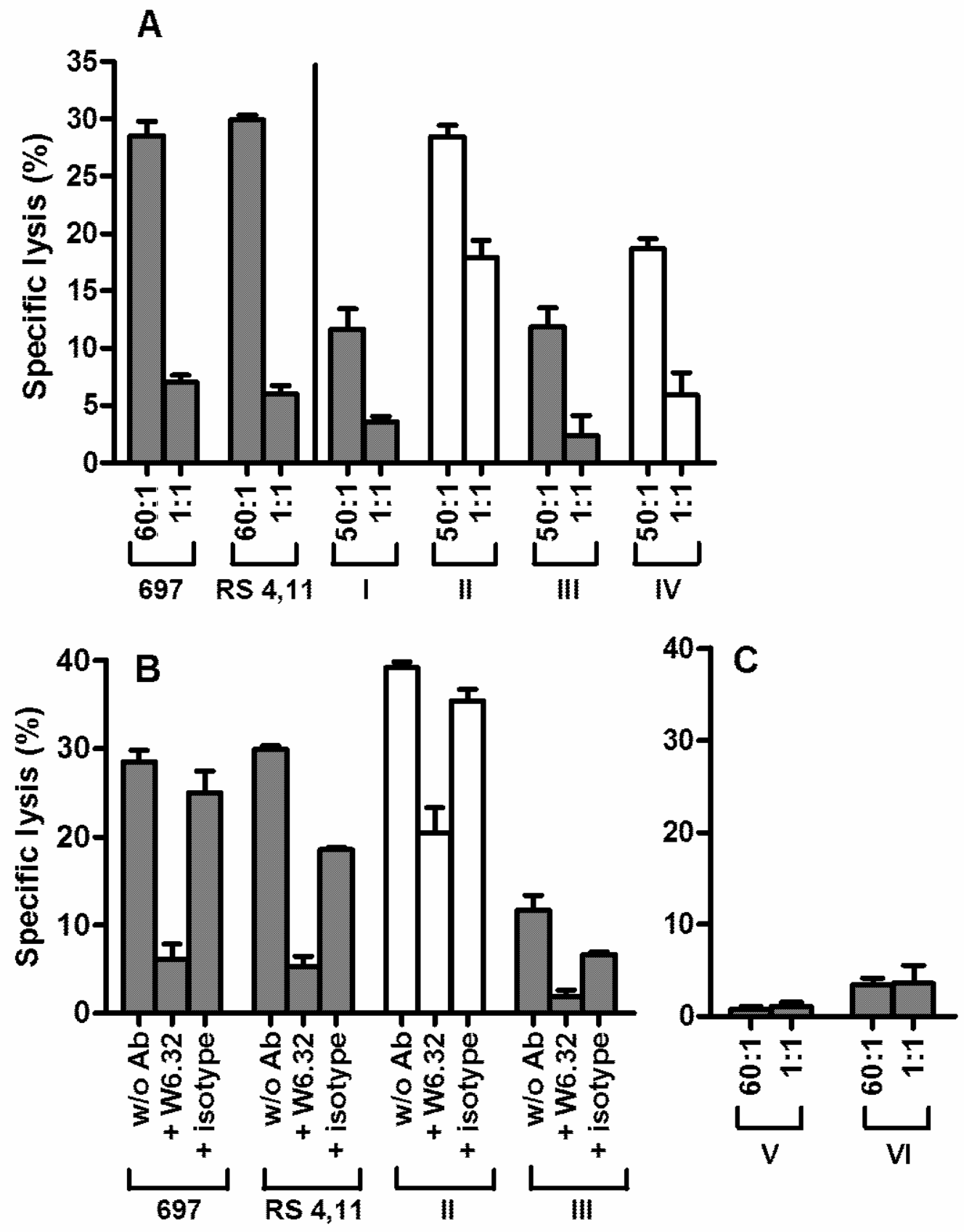

Figure 6 


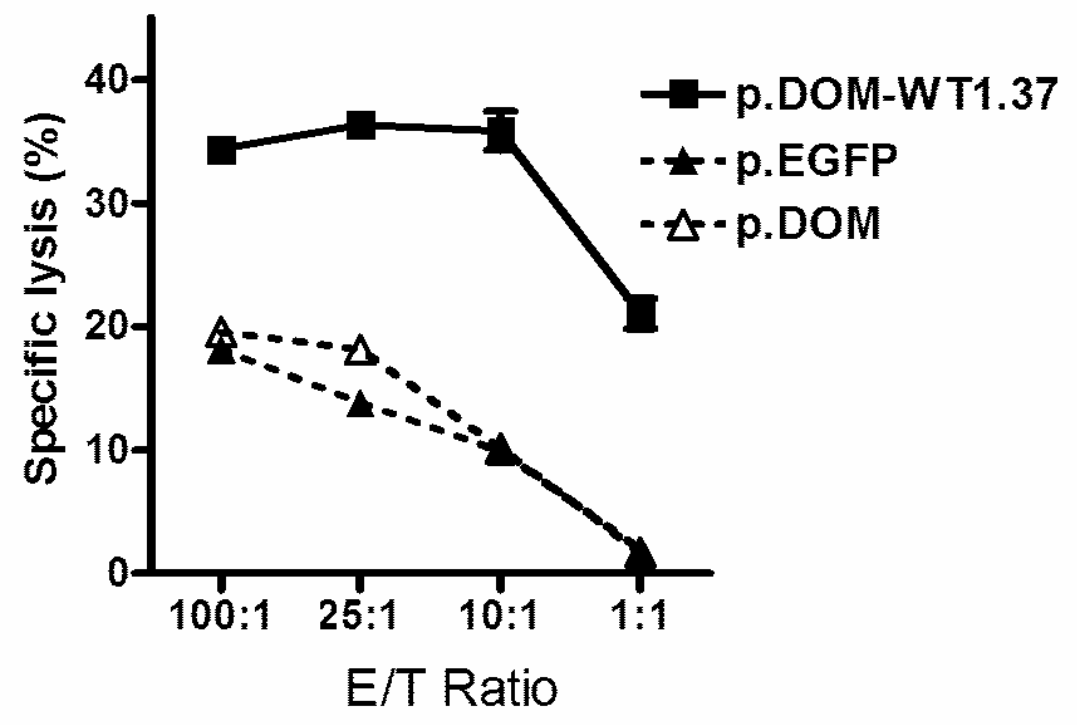

Figure 7 